\title{
The Historical Taboo: Colonial Discourses and Postcolonial Identities in Belgium
}

\author{
JULIEN BOBINEAU \\ University of Würzburg \\ Neuphilologisches Institut / Romanistik \\ Philosophische Fakultät \\ Julius-Maximilians-Universität Würzburg \\ Am Hubland \\ 97074 Würzburg, Germany \\ julien.bobineau@uni-wuerzburg.de
}

\begin{abstract}
This article examines so-called colonial discourses in Belgium related to the former Sub-Saharan colony owned by Leopold II of Belgium which today is known as the Democratic Republic of Congo (DR Congo) or the Congo-Kinshasa. Having introduced the colonial history of the DR Congo from the $15^{\text {th }}$ century until 1910, the study starts with a discussion of Van den Braembussche's concept of a 'historical taboo' and four ways of engaging with such implicit interdictions. Finally, an empirical analysis of colonial discourses in Belgium from the 1890s until today will be presented in conjunction with Belgium's linguistic-cultural division, taking into account age-related divergence.
\end{abstract}

Keywords: DR Congo; Belgium; Leopold II; colonial memory; historical taboo; postcolonial studies; politics of memory; Flanders; Wallonia

\section{Introduction}

The formal end of colonialism at the beginning of the 1960s transformed the previously oppressed populations in Africa, Asia, Oceania, and South and Central America from marginalised objects to human subjects. From a historical 
perspective, these postcolonial societies from the so-called Global South rank among the losers of history even after the - in most cases hard fought for - attainment of their human dignity. It is so because immediately after decolonisation, one looks in vain for a colonial discourse ${ }^{1}$ that reviews European foreign domination in all its facets and puts the formerly colonised populations into focus. The debate about the Second World War was still present in the European public sphere, issues of European unification were hotly debated, and overarchingly, the Cold War dominated daily political events. At the time, especially the prominent colonial actors, such as France, Portugal and the United Kingdom, were apprehensive about the discourse concerning their own colonial past. However, the less prominent colonial nations, including Germany and Belgium, were silent on the subject as well. The reason was obvious: as the entire continent was literally under reconstruction and almost all European countries counted among the culprits of colonialism, the issue was avoided, so as not to taint the newly formed entity of Europe and a shyly growing European identity with moralistic reproaches of colonial exploitation. At this point, one may speak of a 'colonial amnesia' or the conscious creation of historical taboos regarding the colonial past. ${ }^{2}$ The colonial amnesia admittedly at first seems to be a Pan-European phenomenon. ${ }^{3}$ However, there are national differences regarding the tabooing of the colonial past.

The focus of this article is the former colonial power of Belgium and its engagement with certain episodes of its own colonial history in the former colony Congo Belge - known after the independence as Republic of Congo (1960-1964), Democratic Republic of Congo (1964-1971), Zaïre (1971-1997) and again Democratic Republic of Congo (since 1997). From a sociological perspective, Belgium appears particularly attractive for a deeper analysis due to its linguistic-cultural division. After a brief historical introduction, as well as some theoretical deliberations on coping strategies of historical taboos by Antoon Van den Braembussche, it will be discussed to what extent one can speak of a historical taboo in Belgium regarding the handling of their colonial past. On the one hand, the generational differences regarding the specific discourses of Belgian colonial history illuminate both the historical tabooing as well as its overcoming. On the other hand, the region-specific nature of the colonial discourse in Flanders and in Wallonia is in the centre of the analysis.

\footnotetext{
${ }^{1}$ A colonial discourse is a system of statements which includes colonialism as a historical discourse topic. The colonial discourse includes all textual, audiovisual, material and practical products related to the colony/former colony, the country of colonial rulers/the land of former colonial rulers, as well as to third parties throughout the colonial period and to the impact of the colonial era on the present situation.

${ }^{2}$ The term taboo is borrowed from Sigmund Freud's deliberations. Freud referred to taboo as "Holy dread," which "[...] expresses itself essentially in prohibitions and restrictions" (Freud 1919: 31).

${ }^{3}$ So, for example, in France, the Algeria War (1954-1962) was only allowed to be officially referred to as a war from the end of the 2000s onwards.
} 


\section{Historical and theoretical introduction}

The colonial history of the present-day DR Congo began in the $15^{\text {th }}$ century when the local Kingdom of Kongo was a strong federal political entity, consisting of various ethnic groups, each with their own royal house. ${ }^{4}$ Good trade relations between the Portuguese and the heads of the Congo Kingdom developed immediately after the landing of Portuguese sailors on the Atlantic coast in 1482. However, almost 100 years later it came to confrontations in which the militarily stronger Portugal had the upper hand. The Kingdom of Kongo fell apart and, at the same time, became a victim of the transatlantic slave trade, which strongly decimated the population of local ethnicities in the Congo Basin - also with the help of African slave traders.

From the mid-19 ${ }^{\text {th }}$ century on, another European nation, along with Portugal, was interested in the lands in the Congo Basin: while searching for worldwide recognition, Leopold II of Belgium, was granted the ownership of the lands in the Congo Basin within the frame of the Berlin Conference in 1884/85. During this conference, the borders of the European areas of influence in sub-Saharan Africa were set in the presence of the large and most powerful European countries - however, without African participation. In the side agreements of the Berlin Conference, Leopold II raised claims to the Congo Basin territory, which were legitimised by international (Western) standards. Leopold II subsequently established the État indépendant du Congo (E.I.C.) and, in consequence, became the private owner of a land 75 times the size of Belgium. The Belgian king then founded trading companies that were systematically exploiting the country under the guise of free trade.

Especially the rise of the global demand for rubber in the 1890s brought a mass expropriation, forced labour, and enslavement to Congo. During the rubber boom, officers of the colonial army, Force Publique, looted whole villages, took women, children, as well as tribal chiefs as hostages and did not release them again until the men had harvested a fixed amount of rubber. If a man refused to collect rubber or he did not meet the required quota, the hostages were killed. The conditions in which the hostages were kept were inhumane: the people suffered from malnutrition and consequences of poor hygiene. Torture and rape by the colonial soldiers occurred with cruel regularity. However, also Congolese in low positions committed atrocities: simple soldiers, who came from the indigenous population, had to deliver a separated hand of a killed person to their boss in exchange for each rifle cartridge provided by white officers - as proof that the cartridge was put to proper use and not used for hunting. To be able to freely use

\footnotetext{
${ }^{4}$ For a summary of the history of Congo see Bobineau 2016.
} 
the cartridges nonetheless, the soldiers of the Force Publique began to cut off the hands of their living countrymen and to smoke them for better durability and reusability. According to estimates by publicist Adam Hochschild, more than a half of approximately 20 million inhabitants died under the reign of Leopold II as a consequence of forced labour (Hochschild 1999: 232-234). ${ }^{5}$ These so-called Congo atrocities outraged the international community and forced Leopold to sell his colony to the Belgian state in 1908, when it became the Congo Belge. ${ }^{6}$

If one now looks at the way Belgium dealt with these historical events, it is noticeable that Leopold II is the central figure in the colonial records. Within the framework of his colonial justification strategy, he always emphasised that his mission in the Congo was a purely civilisational and consistently philanthropic venture. This emphasis on the humanitarian aspect reached its height shortly after the death of Leopold II. In the 1910s Belgian historians gradually began to glorify the deceased king in order to justify the purchase of the colony prior to the first anti-colonial sentiment in Belgium. In Belgian schools, the image of the imperial, but benevolent philanthropist, who had brought civilisation to the Congo, was imparted (De Heusch 2002: 19). This image fulfilled its purpose because most Belgians finally accepted the takeover of the colony with the proviso that the 'wild Africans' must be treated paternalistically and that they had to be dressed, missionised and civilised. This hierarchical relation of subordination and superordination was clearly visible and led to the positive conservation of the image of Leopold II, especially by the Belgian state.

In hindsight, reflecting on the historical events between 1885 and 1908, which were traumatic for the indigenous people of Congo, the question of how to deal

\footnotetext{
${ }^{5}$ Hochschild further compares the so-called Congo atrocities to the Holocaust (De Mul 2012: 163-168). Also Antoon Van the Braembusche describes the events in the E.I.C under Leopold II as "Congolese Holocaust" (Van den Braembussche 2002: 43). The Holocaust terminology is controversial in Belgium to this day. So the historian David van Reybrouck declined the use of the terms Holocaust or Genocide in his monograph in 2010 Congo. Een geschiedenis and refers to the fact that "[i]t would be absurd in this context to speak of an act of 'genocide' or a 'holocaust'; genocide implies the conscious, planned annihilation of a specific population, and that was never the intention here [in Leopold's II EIC], or the result. And the term Holocaust [sic!] is reserved for the persecution and annihilation of the Jews during World War II" (Van Reybrouck 2014: 95). Guy Vanthemsche (2007: 40) also argues against the term genocide stressing that no systematic killing of the Congolese population has taken place. This approach is however quite problematic. If one defines genocide as an intentional action to eliminate a national, religious, ethnic or racial group, the events in E.I.C. could very well be identified as a genocide that was economically motivated. In many cases, serious consequences of forced labour, systematic torture and mutilation so that rubber quotas could be met, led to death. Furthermore, the use of the term Holocaust exclusively when referring to the extermination of Jews during the time of national socialism is debated in history departments as; for example, David M. Crowe applies the terminology to the destruction of the Roma during the Nazi-period (Crowe 2000: 179-202).

${ }^{6}$ With regard to the international protest against Leopold's II activities, the Congo Reform Association (C.R.A.) founded by Roger Casement and Edmund D. Morel in 1904 needs to be mentioned at this point. The C.R.A. supported the rights of indigenous people as the first organised human rights movement of modern times and called for the abolition of the exploitative system in the Leopoldian private colony.
} 
with the colonial past needs to be answered by Belgium. This colonial past is until today tabooed by most parts of Belgian politics, historiography and society. A look at the considerations of the Flemish historian Antoon Van den Braembusche regarding historical taboos offers a useful basis for an analysis. According to him, there are four different strategies to cope with historical taboos: ${ }^{7}$

(1) The ideological falsification of history strategy

With this type of ideological distortion of history, the existence of historical facts is denied by official institutions or presented as a fictional invention of opponents. In extreme cases, this strategy may lead to history-distorting consequences in the collective remembrance and also in historical publications.

(2) Cognitive strategy

A second coping strategy is the cognitive type, which is based on a new interpretation of incriminating historical facts. This way of dealing with the historical taboo tries to bring past historical events in line with views of the present. It creates a cognitive dissonance or an incompatibility between different cognitions of a person (Festinger 1957: 18-19). With historical taboos, the cognitive dissonance is identified through a discrepancy between the current identity and historical knowledge.

(3) The subconscious repression strategy

A third, much more devious type follows a subconscious repression and simultaneous rejection of historical facts, of which each is based on collective fears and thus may negatively affect a possible identity formation.

(4) Mythical strategy

With the mythical type, historical facts are transformed into a myth, an identity-forming, emotionally charged and only partially verifiable narrative of the past. An alternative past that appears as a dynamic narrative extension is constructed for the purpose of legitimising or forming an identity.

\section{The 'colonial oblivion' in Belgium}

If these preliminary considerations are transferred to the former colonial power in Belgium, it quickly becomes clear that the historical taboo - the colonial period under Leopold II and beyond - is dealt with mostly by applying the strategy of ideological historical falsification. The implementation of a political, ideological falsification of history took place especially in the teaching and research activities of schools and universities: in the 1970s, the Belgian Ministry of Education and Cultural Affairs considered withdrawing history lessons in general

\footnotetext{
${ }^{7}$ The following list is based on the statement by Van den Braembussche (1998: 106-109).
} 
from school curricula (Castryck 2006: 76). The plan was discarded, but school textbooks still impart the outdated image of "[...] Belgian heroism, until Congo disappeared from history courses altogether" (Castryck 2006: 78). Similar problems can be observed in the Belgian historiography. Belgian historians had great difficulties anchoring the colonial past in the national history of Belgium. Many African studies research institutes in Belgium were closed immediately after the Congolese independence in 1960 and remaining institutions shifted their research focus to non-political - and thus more innocuous - subject areas such as linguistics, agriculture, and geology (Castryck 2006: 78). A good example is public Royal Museum for Central Africa (RMCA) in the Brussels suburb Tervuren, which Leopold II had built in 1898 as the Congo Museum with the proceeds from the export of Congolese rubber. Until the temporary closure of the Museum in 2013, both research areas as well as exhibition spaces were reduced mainly to the above-mentioned non-political topics, yet, the exhibitions still focused on the glorification of Leopold II's civilising mission. ${ }^{8}$ Only in the beginning of the 2000s, pronounced public criticism of the objectivity of the museum institution made it impossible to maintain such an image of history. According to Jean Muteba Rahier, the permanent exhibition of the RMCA was blamed for this in particular because still in 2001 it continued to display the former colonial racism by keeping the museological basic concept from the colonial era: "White bodies are clearly different from black bodies in terms of a dichotomy: powerful, civilised, heroic, and dominant versus weak, savage, anonymous, and dominated" (Rahier 2003: 69). In Rahier's opinion, the basic idea of the museum had not changed since its founding up to the year 2001, because "[...] when going through the revolving doors of the museum's main entrance, one has the feeling of entering into a liminal space, frozen in time. One could almost think that the Congo is still a Belgian colony" (Rahier 2003: 62). Due to this manner of presentation, the museum was in the public discourse accused of forging a "distorted vision of history" (Wrong 2001: 58) in its research section, as well as by means of the permanent exhibition.

Such controversial discussions about the museum that seemed to be above any criticism until the 2000s clearly show that one of the most influential institutional symbols of a one-sided colonial past is nowadays questioned by social forces. While the Belgian government barely backs away from its historical-political program, opposite and critical tendencies directed against the glorification of Leopold II and against maintaining the outdated history have developed in the Belgian society. The Belgian writer Théophile de Giraud poured red paint over a monument behind the Royal Palace in Brussels that displays

\footnotetext{
${ }^{8}$ The RMCA is to be reopened in June 2018 with a revised exhibition concept.
} 
Leopold II sitting on a horse. In 2004, members of the Flemish group De Stoete Ostendenoare sawed off a hand of a Congolese slave figure of the equestrian statue in Ostend, which was built in 1931 to honour Leopold II. The reference to the Congo atrocities at the beginning of the 20th century is evident. Laurent Licata and Olivier Klein interpret this action as an attack on a "[...] vector of the official memory put forward by the authorities: cast in bronze, commemorated in collective rituals, taught in schoolbooks" (Klein and Licata 2010: 47). Ostende's local government has responded to the protest and the burgeoning colonial discourse in Belgian society. According to Eddy Surmont, it did not only have the statue restored but also looked at the figure with the cut off hand as a "[...] témoin du passé colonial ténébreux de Léopold II" (Surmont 2007: 9). ${ }^{9}$ In 2010, in the context of a funeral march in the memory of the murdered Congolese Prime Minister, Patrice Lumumba, in Ostend, the colonial critical collective Collectif Mémoires Coloniales et Luttes contre les Discriminations (CMCLD) replaced the cut off hand with a hand made of chocolate. With this gesture the Association made a metaphorical reference to the exploitation of raw materials in Congo: the 'chocolate nation' of Belgium must answer for the origin of its wealth. ${ }^{10}$ The hand made of chocolate was cut into pieces and given to the Congolese participants present at the funeral march as symbolic reparation.

The significant turning point in the awareness of the Belgian society is obvious. According to the Flemish newspaper De Morgen, the interest of Belgian citizens in Central Africa has never been as big as in the $21^{\text {st }}$ century and even exceeded the pronounced interest in Africa during the late colonial period in the 1950s ("En wat met Congo..." 2010). But contrary to that general interest, the above-mentioned colonial critical initiatives arise mostly from the younger population; that is why the increased, discursive interest in a critical colonial self-reflection can be traced back to a generational conflict within Belgian society. According to the study by Licata and Klein, there are two radically different versions of the Belgian colonial history:

The first [...] is a narrative of civilization and development accomplished by the Belgians, under the guidance of Leopold II [...]. The second representation [...] presents colonialism as a large-scale enterprise of systematic human rights violations - forced labor, bloody repression of uprisings, atrocities - for the benefit of first an unscrupulous king, later a nation of shameless exploiters. (Klein and Licata 2010: 46-47)

In their study from the year 2010, Licata and Klein come to the conclusion that the colonial view of history in Belgium is clearly generationally dependent.

\footnotetext{
9 "[...] witness of the dark colonial past of Leopold II" (translated by the author).

${ }^{10}$ The tradition of Belgian chocolate found its heyday during the colonial period as the chocolatiers integrated the Congo belge in their marketing concepts.
} 
Especially the Belgians who were born before 1960 (average age of the study group: 74 years), see the Belgian colonial past as a positive episode, while especially the young generation (average age of the survey group: 20) pursues a critical colonial position in relation to the Belgian past (Klein and Licata 2010: 45-57). According to the study, a third-generation (average age of the survey group: 49) developed "[...] an intermediate position between these two generation groups, suggesting that the trend is progressive" (Klein and Licata 2010: 54). The researchers explain this thesis with the age-based socialisation of the particular generations: while the colonial generation - due to the glorification of historical politics - grew up convinced that the Belgian government in Congo would serve a positive, civilisational and humanitarian-oriented mission, the younger generation grew up "[...] in a much more critical ideological environment. They only remember the worst aspects of colonialism, perceive the colonial King as a cruel megalomaniac, and report guilt to the extent that they feel informed about colonialism" (Klein and Licata 2010: 54).

However, an important aspect must be considered when taking a close look at the older generation in the study. According to the estimates by Florence Gillet, in 2005 there lived about 30,000 Belgian nationals in Belgium who had worked as settlers in the Congo or Ruanda-Urundi for a longer time and lived there during the colonial era (Gillet 2008: 86). ${ }^{11}$ This group of people, which formed the subject-matter of Gillet's empirical study, was at the age between 73 and 93 years at the time. In the evaluation of the questionnaires, Gillet was speaking of an "idéalisation de l'entreprise colonial" (Gillet 2008: 101) ${ }^{12}$ on the part of the polled people that culminates in a strong feeling of nostalgia: ${ }^{13}$ " $80 \%$ d'entre eux gardent une image positive de la colonization" (Gillet 2008: 101). ${ }^{14}$ The Belgian journalist Hugues Dorzee, who quoted several anonymous former colonisers in an article published in 2008, came to a similar conclusion: "Grâce à nous, le Congo et les Congolais sont passés d'un état sauvage à une Nation civilisée' [...]. 'Avec le recul, les Belges peuvent avoir le sentiment du devoir accompli. De très bons gestionnaires au service du bien-être d'un pays et de ses habitants [...]"' (quoted by Dorzee 2008: 19). ${ }^{15}$ A result of this transfiguring nostalgia is a ritualised reminder of the colonial period, such as the annual commemoration of the Association des Anciens et Amis de la Force Publique du Congo Belge that

\footnotetext{
${ }^{11}$ Gillet excludes the numerous Belgian missionaries from the empirical survey without further justification.

12 "idealisation of the colonial enterprise" (translated by the author).

${ }^{13}$ Benjamin Rubbers (2008: 126) refers to the nostalgia as emotional remembrance practice.

14 " $80 \%$ of them retain a positive image of colonization" (translated by the author). Gillet somewhat deadens this value by referring to the specific age of the settlers.

15 "'Thanks to us, the Congo and the Congolese people have gone from a wild state to a civilized nation.' [...] With distance, the Belgians can feel a sense of accomplished duty. Very good managers at the service of the well-being of a country and its inhabitants" (translated by the author).
} 
still takes place today. This nostalgia is reinforced in the retrospective through the so-called perseverance effect: the opinion a person originally formed about an event is difficult to change later on, even if it is proven to be not true at a later time (Bierhoff and Frei 2011: 182). This nostalgia is significantly stronger among former settlers, who are active in clubs glorifying colonial life. Thus, the associations that were formed by former Belgian settlers during or after the colonial period play a crucial role regarding the colonial legacy in Belgium and increase the perseverance effect. As the governing body of the multitude of associations of its kind, the Association Union Royale Belge pour les Pays d'Outre-Mer (UROME) tries to preserve positive memories of the colonial period. André Schorochoff, an official of the association, seems to be convinced of the colonial 'oeuvre': "Nous avons grandement contribué au développement des Congolais. Le progrès accompli là-bas durant les colonies est immense [...]" (quoted by Dorzee 2008: 19). ${ }^{16}$

Furthermore, the representation of UROME even develops historic-revisionist traits when the Honorary President of the Association, Oscar Libotte, keeps claiming: "Les Congolais étaient, en effet, loin d'être les victimes d'un régime répressif [...]" (quoted by ibid.), ${ }^{17}$ because in his view not the actions of the Belgian colonisers, but the law of traditional tribal culture was much more responsible for the "aspects inhumains" (quoted by ibid.). ${ }^{18}$ According to Gillet, this revisionism is taking place simultaneously in association periodicals and monographs, as well as at meetings and conferences of the groups, because these "[...] témoignent également d'une volonté de réécrire l'histoire à leur manière" (Gillet 2008: 120). ${ }^{19}$ In addition, a general tendency to the 'royalism' is discernible among most of the former settlers and supporters of colonial clubs, because the Belgian royal house is imbued with the transfigured glory days of colonialism like no other institution (Gillet 2008: 127).

This observation suggests another differentiation regarding the colonial discourse in addition to the generation-related rift of the country, which finds its origins in the geographical and linguistic division of Belgium. The Flemish part of Belgium is generally critical of the monarchy because the royal succession has always been francophone. According to a joint survey of the Walloon newspaper La Libre Belgique and the Flemish newspaper De Standaard in 2010, almost half of the Flemings (46\%) generally rejected the Belgian monarchy while only $26 \%$ of the Walloons demanded a Belgian republic without a royal house (RTBF 2010;

\footnotetext{
16 "We have greatly contributed to the development of the Congolese people. The progress made there during the colonie is immense" (translated by the author).

${ }_{17}$ "The Congolese were far from being the victim of a repressive regime $[\ldots]$ " (translated by the author).

18 "inhuman aspects" (translated by the author).

19 "[...] also reflect a desire to rewrite history in their own way" (translated by the author).
} 
Buxant and Samnyn 2011: 16-23). The rejection of the francophone monarchy, which was temporarily connected with the Belgian colonialism because of Leopold II's one-man rule of the Congo, also leads to a differentiated perception of the colonial past. While the mainly royalist, francophone Walloons take part in the colonial discourse in a far less critical way, the colonial criticism in Flanders appears much more pronounced. ${ }^{20}$ That, for example, sometimes highlights the discussion (or lack thereof) of colonial history in Belgian textbooks in French while textbooks in Dutch critically questioned the historical figure of Leopold II. Even though the debate started at the beginning of the 1990s, the francophone school textbooks only followed this change of paradigm in the middle of the 2000s (Planche 2009: 277-278). ${ }^{21}$

This hypothesis can be supported further through the colonial linguistic history of today's DR Congo. At the beginning of the Belgian colonial period, the Belgian colonial administrators debated whether the wide dissemination of a European language should be abandoned in the colonisation of the Congo in favour of African languages (Fabian 1983: 167). This, however, would not have corresponded with the contemporary, colonial argumentation of a superiority of the white race. On the other hand, Leopold II and the Belgian government tried to curb the British sphere of influence in Africa, to bind the Congo through a controlled language education, and thus maintain the supremacy in the affected areas in the long term. A choice was finally made when searching for a 'Belgian' colonial language when French was chosen in 1886 as the official language of the courts (Calvet 2010: 117). Some Flemish missionaries initially refused to teach in the French language but had to give in later because of the pressure coming from Brussels (Yates 1980: 263). Therefore, the continuous Belgian language dispute that had been simmering since the beginning of the establishment of the state was also being conducted in the colony, far from the European metropolis.

The rationale for the choice of French as the official language of the former colony was obvious at that time, since Leopold II's French mother, Louise of Orléans - Louis Philippe's eldest daughter - could only speak the French language and thus raised Leopold II as a French-speaking monarch. ${ }^{22}$ It is reasonable to

\footnotetext{
${ }^{20}$ The interest in the Congolese colony was already far more pronounced in the Walloon part of Belgium at the colonial times than in Flanders (Jacquemyns 1956: 12).

${ }_{21}$ According to Stéphanie Planche, French textbooks adopt a far more defensive stance relating to the interpretation of historical facts, because "[...] il s'agit cette fois plutôt de trouver des éléments à la décharge de Léopold II" (Planche 2009: 278; “[...] this time, it is rather to find arguments to discharge Leopold II" (translated by the author)).

${ }^{22}$ Leopold II also learned the German and English languages because of his family relations to the English royal house and because of the German descent of his father, but, according to Barbara Emerson, he did not master the Dutch language throughout his life: "The novelist, Henri Conscience, whose writing encouraged the Flemish national movement in its early days, was appointed teacher of Flemish to the royal children, but it was purely honorific and Prince Leopold [II] never learned to speak Flemish" (Emerson 1979: 7).
} 
assume that the king was trying to keep his private colony francophone based on his own language skills. Secondly, the colonial activities of France in West and Central Africa also suggested that the French language - in addition to English - would develop into an African Lingua franca, which is also why the cultural relationship of Belgium with France influenced the choice of the French language. The third aspect includes the official Belgian language policy that divided the Belgian country over the course of the language dispute until today. From a governmental perspective, the French language in Belgium has been considered as the qualitatively superior language since the establishment of the Belgian state. Because French was perceived as an elitist language in the middle of the $19^{\text {th }}$ century it was raised to the initial sole Belgian national language. Yet, because of protests of the Dutch-speaking population, which still accounts for approximately $60 \%$ of the Belgian residents, the position of the Dutch language became stronger. The Flemings centrally organised themselves in the Vlaamse Beweging ${ }^{23}$ and the Flemish language received legal encouragement in Belgium from 1873 in the shape of equality laws (Hasquin 1982: 35-38). In 1898 it was declared the official second language of Belgium in addition to French (Krämer 2010: 31).

This legal equality also had far-reaching consequences for the language of the colony. In the transition phase from 1907 to 1910 - after the sale of the E.I.C. to the Belgian state by Leopold II in 1908 - the debate about the significance of Dutch was transferred to the colony ${ }^{24}$ because the Flemings were now also insisting on their growing importance in the colony (Calvet 2010: 117) and that the equality of both languages for the Congo as a Belgian territory in 1908 had to be granted at least from a theoretical, legal perspective. According to the legal equality of the two national languages in Belgium, the Catholic or Protestant missions, whose missionaries maintained close contact with the Congolese population, could initially choose individually between Dutch and French as language of education (Fabian 1983: 171). Due to the postulated superiority of the French language in Belgium, most missionaries, including Flemish priests, chose French in order to also linguistically suit colonial hierarchies and dichotomies of superior - inferior/civilised - uncivilised. ${ }^{25}$

\footnotetext{
${ }^{23}$ Due to the fact that the group of the first consciously Flemish citizens consisted of writers and philologists, the language question in Belgium is/was politicised in such ways and simultaneously represents the basis of the Flemish national movement until today (Vinks 1978: 17).

${ }^{24}$ In addition to the debate, whether the Congolese should be taught in French or Dutch, there were further discussions in Belgium if the access to a European language should be granted to the native people - for fear of the rise of an African elite (Yates 1980: 272-273). Furthermore, a debate about the general significance of the African languages flared up (N'Sial 2009: 51-55). The européanistes did not consider the local African languages and dialects as 'Languages' and called for the full dissemination of European languages. The indigénistes, however, opposed this language imperialism and pleaded for a focus on African languages.

${ }^{25}$ Only at the beginning of the 1950s, the representatives of Flanders succeeded in officially embedding the Dutch language in the Congolese educational system and to integrate the Dutch in the
} 
The decision of the Belgian colonial administration to implement the French language as the official language in the former colony has not remained without consequences even in the postcolonial era. The fact that the French language still serves as an official language in addition to the four Congolese national languages Kikongo, Lingala, Swahili and Tshiluba, is reflected in postcolonial migratory movements. In the case of migration, it is important to note that people from former colonies usually prefer the former 'mother country' as a destination regarding the global flow of migration. The bilateral treaties between the former colony and the former 'mother country' certainly ease the entry. However, according to József Böröcz and Alejandro Portes (1989: 609), not only this aspect is relevant to the choice of place of residence. Economic, social, linguistic and cultural dependencies resulting from colonialism are much more significant. Statistical data by Quentin Schoonvaere, in respect of the Congolese state citizens living in Belgium in 2006, proves this assumption. While a total of $79,81 \%$ of the Congolese lived in the francophone Wallonia and the French-speaking districts of Brussels, only 20,19\% of the immigrant Congolese chose to reside in Flanders ("Etude de la migration..." 2010: 59). Due to this spatial migration-related distance of Congolese people, as well as the above-mentioned linguistic distance to the former colony, it is probably easier for the Flemish part of the Belgium to take on a critical colonial attitude because the colonial activities do not fall into their own, identitarian scope of action.

A further political sociological aspect is, until today, that the Flemish population feels more closely connected with the Congolese people than the Walloon part of Belgium. This stems from the fact that the Flemish, similarly to the Congolese population in the course of the initial colonisation, were also suppressed by the exclusively francophone royal house and the French-speaking bourgeoisie that occupied many key positions in the colonial administration. ${ }^{26}$ According to Caty Clément and Claude Roosens, the Flemish suffered from a similar - though not fully colonial - suppression in their home country of Belgium, as well as in the Congolese colony: ${ }^{27}$ "La bourgeoisie francophone aurait [...] capturé l'appareillage administratif, tandis que les petits blancs [...], souvent flamands, auraient trouvé une situation qui n'était pas sans leur rappeler la suprématie

colonial language policy; yet, only for a short period, because in 1958, the colonial administration removed Dutch from the curriculum again. Today, the Dutch language does not play any significant role in the DR Congo.

${ }^{26}$ See, for example, a propaganda poster from 1885 with the title De Vlamingen aan de Negers van den Congo, which was exhibited in 2005 at the Musée BELvue in Brussels. The poster compares the discrimination by the Walloons, which the Flemings and the Congolese would suffer equally - according to the inscription: "Hailing the Congolese as 'zwarte broeders' (black brothers), it assimilates the subjugation suffered by the Congo populations in Africa with that suffered by the Flemings at home, and designates the Walloons as their common oppressor" (Bragard and Planche 2010: 57).

${ }^{27}$ For the relation of Flanders to the colony see the extensive statements by Bambi Ceuppens (2003). 
'francophone' qu'ils subissaient dans leur propre pays" (Clément and Roosens 2000: 41). ${ }^{28}$ It needs to be conceded that some Flemish-Belgians were in major positions during the colonial period and exercised power. ${ }^{29}$ However, the image of the oppressed Flemings that acted as a stooge on orders for the French-speaking bourgeoisie was transferred to the colony as well. Currently this image is employed to shift the responsibility off the Flemish. The explanation works as follows: because the Flemings were suppressed in Belgium as well as in the colony by the francophone leadership and thus had no active influence on fundamental colonial (and even postcolonial) decisions, but only conducted orders of the superior Walloons, the Flemish have no responsibility in the self-perception today regarding the colonisation of the Congo and its consequences.

\section{Conclusion}

The emergence of a critical colonial self-reflection in Belgium is located particularly among the young and historically unburdened generation. At the same time, a stronger critical stance towards the colonial discourse with regards to historical, linguistic, and sociological aspects can be observed among the anti-royalist Flemish part of the population. Taking into account the theoretical model by Van den Braembussche it is now evident that Belgians dealing with their own colonial history are facing a historical taboo at this point. According to Van den Braembussche, various mechanisms have emerged in Belgium to cope with this taboo. (1) The phenomenon of ideological distortion of history is found in the official history politics in Belgium, especially regarding the public education sector and also the State Museum in Tervuren, which propagates a different, glorified colonial reality. (2) At the same time, not only parts of colonial history are negated, as proffered by the cognitive type coping strategy, but are also reinterpreted according to an ideological doctrine. The justification with an emphasis on the philanthropic mission of civilisation, particularly in relation to the older generation of Belgians, needs to be highlighted here. (3) The subconscious suppression strategy can be observed mainly amongst the older generations in Belgium. They seem significantly influenced by the first two coping strategies. (4) The mythical type is not found in Belgium - in contrast to the societies of the modern DR Congo.

The justification for the coping strategies dominating in Belgium can be found by looking at the different regional identities. The young monarchy, which just

\footnotetext{
28 "The Francophone bourgeoisie would have [...] engrossed the administrative apparatus while the petits blancs [...], often Flemish, would have found a situation that was not unlike the French-speaking supremacy that they suffered in their homeland" (translated by the author).

29 The mainly Flemish, Catholic missions are a particular example (De Villers 2000: 169).
} 
celebrated its independence from the Netherlands in 1830, is still divided to this day. At least three different regional identities are observable together with the three official languages of French, Dutch and German. A unified Belgian national identity proves to be an illusion. Therefore, it is possible that Belgian public institutions use the instrument of ideological historical falsification in order to deal with the historical taboos, to avoid colonial historical controversies. Therefore, the political aim is to unite the divided country through colonial discourse, which has always depicted Belgium as a unified country. The real world consequences of this mistaken policy of forging history through the suppression of a reflected colonial discourse and the maintenance of outdated colonial images are severe. ${ }^{30}$ According to Édouard Vincke, stereotypical prejudices in Belgium persist if the following three aspects are attributed to Afro-descendants: "C'est un noyau thématique dont la topologie se concentre en trois composantes - infantile, sexuelle, sauvage -, qui ont des intensités variables" (Vincke 1993: 97). ${ }^{31}$ Thus, an updated politics of history should be built on a new foundation dedicated to overcoming these stereotypes. At the same time, it is also necessary to deal with the following issues and longtime taboo questions expressed by Sabine Cornelis:

A-t-on suffisament remercié le peuple congolais pour l'effort de guerre qu'il a fourni, à la limite de l'épuisement, pour soutenir les Alliés? A-t-on bien célébré les contingents de la Force publique qui se sont impliqués dans les campagnes des deux guerres mondiales? A-t-on remercié le peuple congolais pour la production et l'exportation des produits industriels du Congo? (Cornelis 2008: 3) ${ }^{32}$

So far it can be observed that issues of a moral reparation in Belgian colonial discourse play a minor role, and that there are only few exceptions that are reflected and critically dedicated to these issues. This is specifically so in the case of public and civil institutions exercising the continued systematic influence, propagating the colonial discourse with the aid of historio-political instruments. However, the slow emergence of a few social forces breaking the taboo shows that critical engagement and the distortion of history politics leads to a different, new identity. The untouchable image of Leopold II has diminished in the last few decades, but it continues to offer a symbolic identification. As a newly defined

\footnotetext{
${ }^{30}$ Jean-Luc Vellut calls for a new, official version of the colonial history at this point (Vellut 2007: 13-14).

31 "It is a thematic core whose topology is concentrated on three components - infantile, sexual, wild - which have varying intensities" (translated by the author).

32 "Did we sufficiently thank the Congolese people for the war effort which they had provided, on the verge of exhaustion, to support the Allies? Did we celebrate the Public Force contingents that have been involved in the campaigns of the two World Wars? Did we thank the Congolese people for the production and export of industrial products from the Congo?" (translated by the author).
} 
enemy image, it is used by the generation of young Belgians as the basis for an updated, collective and at the same time colonial-critical partial identity.

\section{Bibliography}

Bierhoff, Hans-Werner, and Dieter Frei. 2011. Sozialpsychologie - Individuum und soziale Welt. Göttingen et al.: Hogrefe.

Bobineau, Julien. 2016. "The History of the Democratic Republic of Congo." The Democratic Republic of the Congo. La République Démocratique du Congo. Eds. Julien Bobineau, and Philipp Gieg. Berlin: LIT Verlag. 11-28.

Bragard, Véronique, and Stéphanie Planche. 2010. "Museum Practices and the Belgian Colonial Past: Questioning the Memories of an Ambivalent Metropole." Museums in Postcolonial Europe: Africa and the Black Diaspora. Ed. Dominic Richard David Thomas. London: Routlegde. 54-64.

Buxant, Martin, and Steven Samyn. 2011. Belgique, un roi sans pays. Paris: Plon.

Böröcz, József, and Alejandro Portes. 1989. “Contemporary Immigration: Theoretical Perspectives on Its Determinants and Modes of Incorporation." International Migration Review 23(3): 606-630.

Calvet, Louis-Jean. 2010. Histoire du français en Afrique. Une langue en copropriété? Paris: Écriture.

Castryck, Geert. 2006. "Whose History is History? Singularities and Dualities of the Public Debate on Belgian Colonialism." Europe and the World in European Historiography. Ed. Csaba Lévai. Pisa: Pisa Univ. Press. 71-88.

Ceuppens, Bambi. 2003. Congo made in Flanders? Koloniale Vlaamse visies op 'blank' en 'zwart' in Belgisch Congo. Brüssel: Acad. Press.

Clément, Caty, and Claude Roosens. 2000. "La Belgique et le Congo: dimensions internationales et internes." La Belgique et l'Afrique centrale de 1960 à nos jours. Ed. Olivier Lanotte. Brussels: GRIP et al. 17-50.

Cornelis, Sabine. 2008. "Révisiter l'histoire, pour 'réparer." UC Louvain. 17 March 2008. Catholic University of Louvain-la-Neuve. 25 June 2016. <https://www.uclouvain. be/cps/ucl/doc/ac-arec/documents/Cornelis.pdf>.

Crowe, David M. 2000. "The Roma Holocaust." The Holocaust's Ghost. Writings on Art, Politics, Law and Education. Ed. Frederick Charles De Cost. Edmonton: Univ. of Alberta Press. 179-202.

De Mul, Sarah. 2012. "The Holocaust as a Paradigm for the Congo Atrocities. Adam Hochschild's King Leopold's Ghost." The Postcolonial Low Countries. Literature, Colonialism, Multiculturalism. Eds. Elleke Boehmer, and Sarah De Mul. Lanham et al.: Lexinton Books. 163-183.

Dorzee, Hugues. 2008. “Colons au passé et au présent." Le Soir 15 Nov. 2008: 19.

Emerson, Barbara. 1979. Leopold II of the Belgians. King of Colonialism. London: Weidenfeld and Nicolson.

“En wat met Congo na 30 juni?" De Morgen. 23 June 2010. De Morgen. 25 June 2016. $<$ http://www.demorgen.be/ buitenland/en-wat-met-congo-na-30-juni-a1123622/>.

"Etude de la migration congolaise et de son impact sur lapresence congolaise en Belgique: Analyse des principales données démographiques." 1 June 2010. Diversité. Ed. Quentin 
Schoonvaere.. Groupe d'étude de Démographique Appliquée (UCL) \& Centre pour l'égalité des chances et la lutte contre le racisme. 24 June 2016. <http://www.diversite. be/sites/default/files/legacy_files/studies/2010/Etude_Congolais_FR\%5B1\%5D. pdf>.

Fabian, Johannes. 1983. "Missions and the Colonization of African Languages: Developments in the Former Belgian Congo." Canadian Journal of African Studies 17(2): 165-187.

Festinger, Leon. 1957. A Theory of Cognitive Dissonance. London: Stanford Univ. Press.

Freud, Sigmund. 1919. Totem and Taboo. Resemblances between the Psychic Lives of Savages and Neurotics. London: Routlegde.

Gillet, Florence. 2008. “Congo rêvé? Congo détruit... Les anciens coloniaux belges aux prises avec une société en repentir. Enquête sur la face émergée d'une mémoire." CHTP-BEG 19: 79-133.

Hasquin, Hervé. 1982. Historiographie et politique. Charleroi: Inst. Jules Destrée.

Heusch, Luc de. 2002. “Ceci n'est pas la Belgique." Yale French Studies 102: 11-23.

Hochschild, Adam. 1999. King Leopold's Ghost: A Story of Greed, Terror, and Heroism in Colonial Africa. Boston: Houghton Mifflin.

Jacquemyns, Guillaume. 1956. Le Congo belge devant l'opinion publique. Brussels: INSOC.

Klein, Olivier, and Laurent Licata. 2010. “Holocaust or Benevolent Paternalism? Intergenerational Comparisons on Collective Memories and Emotions about Belgium's Colonial Past." IJCV 4(1): 45-57.

Krämer, Philipp. 2010. Der innere Konflikt in Belgien: Sprache und Politik. Geschichte und Gegenwart der mehrsprachigen Gesellschaft. Saarbrücken: VDM-Verlag.

N'Sial, Camille Sesep. 2009. La politique et les langues. De l'Etat indépendant du Congo à la Troisième République. Paris et al.: L'Harmattan.

Planche, Stéphanie. 2009. “Le 'Roi colonisateur' à l'école." Léopold II. Entre genie et gêne. Eds. Vincent Dujardin, and Fancis Balace. Brussels: Racine. 269-283.

Rahier, Jean Muteba. 2003. "The Ghost of Leopold II: The Belgian Royal Museum of Central Africa and Its Dusty Colonialist Exhibition." Research in African Literatures 34(1): 58-84.

Roosens, Claude. 2000. “Belgique-Zaire: la Grande crise.” La Belgique et l'Afrique centrale de 1960 à nos jours. Ed. Olivier Lanotte. Brussels: GRIP et al. 135-148.

RTBF. 2010. “62\% des Belges sont favorables au maintien de la monarchie." Radio-télévision belge de la Communauté française. 27 March 2010. Radio-télévision belge de la Communauté française. 25 June 2016. <http://www.rtbf.be/info/belgique/detail_62-des-belges-sont-favorables-au-maintien-delamonarchie?id=4954343>.

Rubbers, Benjamin. 2008. “Au temps béni de la colonie. Le Congo belge dans la mémoire des anciens coloniaux et des anciens colonisés." Autour de la mémoire. La Belgique, le Congo et le passé coloniale. Ed. Rosario Giordano. Torino: Harmattan Italia. 121-129.

Surmont, Eddy. 2007. “Le mystère de la main sectionnée." Le Soir 27 March 2007: 9.

Van den Braembussche, Antoon. 1998. "The Silenced Past. On the Nature of Historical Taboos." Świat historii. Prace z metodologii historii $i$ historii historiografii dedykowane Jerzemu Topolskiemu z okazji siedemdziesięciolecia urodzin. Ed. Wojciecha Wrzoska, and Jerzy Topolski. Poznań: Inst. Historii UAM. 97-111.

2002. "The Silence of Belgium: Taboo and Trauma in Belgian Memory." Yale French Studies 102: 34-52.

Van Reybrouck, Daniel. 2014. Congo. The Epic History of People. Trans. Sam Garrett. London: Fourth Estate. The original Dutch edition was published in 2010. 
Vanthemsche, Guy. 2007. Nouvelle Histoire de Belgique. La Belgique et le Congo. Empreintes d'une colonie 1885-1980. Vol. IV. Brussels: Complexe.

Vellut, Jean-Luc. 2007. "Préface. Histoire des empires coloniaux. D’où vient-on?" Nouvelle Histoire de Belgique. La Belgique et le Congo. Empreintes d'une colonie 1885-1980. Ed. Guy Vanthemsche. Vol. IV. Brussels: Complexe. 11-22.

Villers, Gauthier de. 2000. "La Belgique face à la transition manquée au Congo-Zaire (1990-1997)." La Belgique et l'Afrique centrale de 1960 à nos jours. Ed. Olivier Lanotte. Brussels: GRIP et al. 149-171.

Vincke, Édouard. 1993. “Discours sur le Noir: Images dans les espaces urbains de Bruxelles." Images de l'Afrique et du Congo/Zaïre dans les lettres françaises de Belgique et alentour. Eds. Pierre Halen, and János Riesz. Brussels/Kinshasa: Textyles Ed. et al. 89-99.

Vinks, Jos. 1978. Der Nationalismus in Flandern. Geschichte und Idee. Vaterstetten: Arndt-Verlag.

Wrong, Michela. 2001. In the Footsteps of Mr. Kurtz. Living on the Brink of Disaster in Mobutu's Congo. New York: HarperCollins.

Yates, Barbara A. 1980. "The Origins of Language Policy in Zaire." The Journal of Modern African Studies 18(2): 257-279. 